\title{
UNDERSTANDING THE DRIVER MOTIVATION OF WOMEN ENTREPRENEURS IN BANDUNG
}

\author{
Cut Irna Setiawati ${ }^{*}$ and Titin Rini Kartini**) \\ *) Business Administration Department, School of Communication and Business, Telkom University \\ Jl. Telekomunikasi No.1, Sukapura, Dayeuh Kolot, Bandung 40257
}

\begin{abstract}
In order to support the increasing number of entrepreneurs in West Java, since 2015 Dra. Mutia Oktaviana as a woman entrepreneur and Disperindag of West Java have established Product Marketing Association (APPU) West Java. This is an association which has 200 members with the composition of 180 female entrepreneurs $(90 \%)$; it has potential to rise by year to year. Therefore, this research aims to know the factors which could motivate the women who are members of APPU West Java to become women entrepreneurs especially in Bandung. This research used quantitative method with descriptive and explorative research. The sample collection utilizes a technique of Nonprobability sampling and insidental sampling with 106 respondents. In addition, the data were analyzed using a factor analyzing technique which could motivate each of the entrepreneurship supporting factors. Based on the factor analyses technique using 21 factors, the results produced the formation of 7 new factors, namely family oriented, family background and friends, income stability, hobby and facility support, public existency, challenges and risks, and phisycal limitation. The most dominant factor is family oriented consisting of the following variables: running business as well as doing housework, having more time with family, creating job opportunity for family member, and the possibility of getting big profit.
\end{abstract}

Keywords: women entrepreneur motivations, factor analysis, APPU

\begin{abstract}
Abstrak: Dalam upaya mendukung peningkatan jumlah wirausaha di West Java, sejak tahun 2015 wirausaha wanita yaitu Dra. Mutia Oktaviana dan Disperindag West Java mendirikan Asosiasi Pemasar Produk UKM (APPU) West Java. Asosiasi ini telah memiliki 200 orang anggota dengan komposisi 180 orang (90\%) women entrepreneur dan jumlah tersebut berpotensi untuk terus bertambah. Maka, tujuan penelitian ini adalah untuk mengetahui faktor-faktor yang mendorong para wanita anggota APPU West Java yang berdomisili di Kota Bandung untuk menjadi women entrepreneur. Penelitian ini menggunakan metode kuantitatif dengan jenis penelitian deskriptif dan eksploratif. Pengambilan sampel dilakukan dengan teknik Nonprobability sampling dan metode sampling insidental dengan jumlah responden 106 orang. Dengan teknik analisis data yang digunakan adalah teknik analisis faktor untuk menganalisis setiap faktor pendorong berwirausaha. Berdasarkan teknik analisis faktor dengan menggunakan 21 faktor, maka hasil penelitian ini adalah terbentuknya 7 faktor baru, yaitu family oriented, family background and friends, income stability, hobby and facility support, public existency, challenges and risks, dan phisycal limitation. Sedangkan faktor yang paling dominan yaitu faktor family oriented yang terdiri dari variabel menjalankan usaha sekaligus melakukan pekerjaan rumah tangga, memiliki waktu lebih banyak dengan keluarga, menciptakan kesempatan kerja bagi anggota keluarga, dan adanya kemungkinan keuntungan yang besar.
\end{abstract}

Kata kunci: motivasi wirausaha wanita, analisis faktor, APPU

\footnotetext{
${ }^{1}$ Corresponding author:

Email: titinrinikartini@gmail.com/irnacut@telkomuniversity.ac.id
} 


\section{INTRODUCTION}

Indonesia is one of the countries that recognize entrepreneurship and entrepreneurship activities in the country to reduce the number of unemployed and poverty (Alifuddin and Razak, 2015). The Government of Indonesia has made various efforts to increase the number of entrepreneurs through many ministries and related parties. The impact of the programs is the increase in the number of entrepreneurs in Indonesia which has reached $3.1 \%$ of the total population in Indonesia or about $8,078,003$ entrepreneurs and has exceeded the ration of minimum entrepreneurs in a country that is $2 \%$ of the total population. The growth of entrepreneurs in Indonesia is divided into Small and Medium Enterprises (SMEs) and has contributed $60.34 \%$ to the Gross Domestic Product (GDP) and $97.22 \%$ to the employment in the last five years (www. cnnindonesia.com, 05 October 2017).

The growth of the number of entrepreneurs in Indonesia is happening in various regions with the highest percentage in the eastern part of Indonesia. Meanwhile, West Java was the province with the lowest growth of entrepreneurs until 2015. However, the West Java Provincial Government has done various efforts to improve the growth of number of entreprenuers and entrepreneurship activities. Dinas Perindustrian dan Perdagangan West Java (Industry and Trade Office of West Java), Dinas Koperasi dan UMKM West Java and related offices from various levels, from regional to provincial level, have made some efforts to conduct some programs to create 100,000 New Entrepreneurs or called WUB (disperindag.jabarprov.go.id, 06 October 2017). The government through www.diskumkm. jabarprov.go.id (on 06 October 2017) made various policies to support the growth of entrepreneurs in West Java. One of the impacts is to increase the Economic Growth Rate or Laju Pertumbuhan Ekonomi (LPE) in West Java which has been decreasing for several years.

Based on the data of Economic Growth Rate (LPE) of West Java in 2012-2016, the economic growth in West Java in 2012-2015 decreased constantly. However, LPE increased in 2015-2016, followed by an increase in employment. This indicates the increasing number of entrepreneurs and business units that exist in West
Java. The increasing number of entrepreneurs in various industries including the scale of SMEs and even large scale is not only owned and managed by male entrepreneurs, but some are owned and managed by women entrepreneurs.

Realizing the potential of running a busines by women entrepreneurs, in 2015 Dra. Mutia Oktaviana and Dinas Perindustrian dan Perdagangan West Java established Asosiasi Pemasar Produk UKM (APPU) West Java. After two years, APPU has 200 active members who spread in some cities and regencies in West Java with $90 \%$ composition or about 180 people are women entrepreneurs and 10\% (20 persons) are men entrepreneurs. The increasing number of interested women to become entrepreneurs cannot be separated from the driving factors, both internal and external. Having the drive in entrepreneurship will make a woman dare to take risks and give her a guide to become a true entrepreneur (Fahmi, 2013).

The results of pre-research carried out by the author regarding some of the drivers of women involvement in entreprenerial activities are: becoming independent (36.5\%), increasing the family income $(27 \%)$, difficulty to find employment (3.2\%), hobby (1.6\%), family background (4.7\%), becoming one's own boss $(3.2 \%)$, creating job opportunity $(20.6 \%)$, and wanting to exist in the community (3.2\%). The data shows that most women entrepreneurs are running an enterprise to become independent, especially financial independence. However, these drivers are based on daily life experiences of women entrepreneurs, not on theoretical studies, so further research is needed.

In addition to the research that the author has been doing, several studies on driver motivations of women entrepreneurs have been conducted by several researchers such as Munawaroh (2012) who conducted research entitled Faktor- Faktor yang Memotivasi Wirausaha Wanita menjadi Pengusaha (Studi pada Pengusaha Wanita Anggota IWAPI DIY), Barani and Dheepa with a research entitled Influence of Motives and its Impact on Women Entrepreneurs in India. Jesurajan and Gnanadhas also conducted research entitled A Study on The Factors Motivating Women to Became Entrepreneurs in Tirunelveli District in 2011, and so did several other researchers. 
Therefore, the purpose of this research is to add references and scientific knowledge to identify the dominant factors that motivate and drive women in choosing and deciding to become the entrepreneurs from the grassroots perspective, such as internal factors or external factors, by studying the APPU. In identifying process, this research focus on one community (APPU) member who domiciles in Bandung to obtain the specific factors.

\section{METHODS}

This research will take place for about 6 months from July to December 2018 and will be conducted in Bandung. APPU as the object of this research is an organization that has 200 members who are crossindustry entrepreneurs, such as the culinary industry, fashion, furniture, accessories, handcraft and others. This research will focus on APPU members in West Java who are domiciled in Bandung, because there are a number of people, 144 people, while other members are scattered in several cities and districts with an uncertain amount in each region.

The population of this research is women entrepreneur of APPU West Java members who live in Bandung. In this study, the population size is 144 people with the fault tolerance limit $5 \%$ or 0.05 . After the authors calculated the number of samples using Slovin Formula, the result shows that in this study there are 106 people. The sampling method in this study is incidental sampling.

Primary data is data obtained from respondents through questionnaires, focus group discussions, and panels, and also data obtained from interviews with resource persons (Sujarweni, 2015). In this study primary data from questionnaires were distributed to women entrepreneurs of APPU members in West Java who were domiciled in Bandung, either through direct information or through the internet.

In addition, secondary data is data that has been processed by a particular party, so that when it is needed the data is available (Sarwono, 2012). In this study, the authors obtained secondary data from several sources, including books containing theories that are relevant to the research of the author, journals consisting of national and international journals, previous theses, and a valid website or internet.

This is a quantitative research with a descriptive and explorative method. The data analysis technique that is used in this research is factor analysis. Factor analysis is a type of analysis technique from multivariate analysis that is used to reduce data which aims to form a linear combination of the initial variables by taking into account as many as possible the initial variable variations that might be used (Amirullah, 2013). The research framework in Figure 1.

\section{RESULTS}

\section{KMO and Bartlett's Test}

By considering the adequacy of the sample and the correlation between factors simultaneously, KMO Test and Bartlett Test Sphericity are used. The calculation result must yield a minimum KMO value of 0.5 with a significance level of less than 0.05 .

Based on Table 1, it can be seen that the result of KMO and Bartlett Test is 0.760 with a significance of 0.000 . This number indicates that the KMO and Bartlett Test values are greater than $0.5(0.760)$ and the significance value is less than $0.05(0.000)$. Thus, the variables and samples in this study can be analyzed further by using factor analysis techniques. In addition, the correlation of factors can partially be seen from the value of Measure of Sampling Eduquacy (MSA) on the test results of Anti Image Matrics.

Table 2 is the result of the Anti Image Matrics calculation with the result that the MSA value for each factor of the 21 factors is above 0.5 . Values mean that every factor can be predicted, and further analysis can be done.

\section{Communalities}

Communalities is one of the most important tests because it can see the relationship between the initial variables and the new variables that are formed. Each factor in the test of communalities is measured using an extraction value of 1,000 . 
The driver factors to be Women Entrepreneur (Zimmerman and Chu 2013): to be my own boss, to be able to use my past experience and training, to prove i can do it, to increase my income, to gain public recognition, to provide jobs for family members, for my own satisfaction and growth, so i will always have job security, to build a business to pass on, to maintain my personal freedom, to be closer to my family, and any other reason

The driver factors to be Women Entrepreneur (Franck, 2012): To earn income, interest in doing business/ like doing business, family inheritance/ experience in the business, bored at home, to be independent, lack of other option/ no other available job, to help a family member, easy operation, possibility to combine with family duties, to get daily rather than monthly income, and physical disability.

The driver factors to be Women Entrepreneur (Jesurajan et al. 2011): Independent economically, dissatisfied with existing jobs, unemployment, looking for challenges, personal desires, self-esteem, traditional/descending, employment opportunities, financial assistance, technical knowledge, family encouragement, use of unused funds, infrastructure facilities, entrepreneurial experience, market potential, family status, and family background.

The driver factors to be Women Entrepreneur Women Entrepreneur (Munawaroh, 2012): Parent entrepreneurs, tired of being employees, want to be the boss, want to be free, want to exist in society, income greater than be an employees, want to help fulfill family needs, want to create jobs, want to take free time, have skill, hobby, basic knowledge of business, family entrepreneur, invited friends, have business capital, want to be independent, salary is not enough, difficult to get a job, not accepted the work, and want to give the best product.

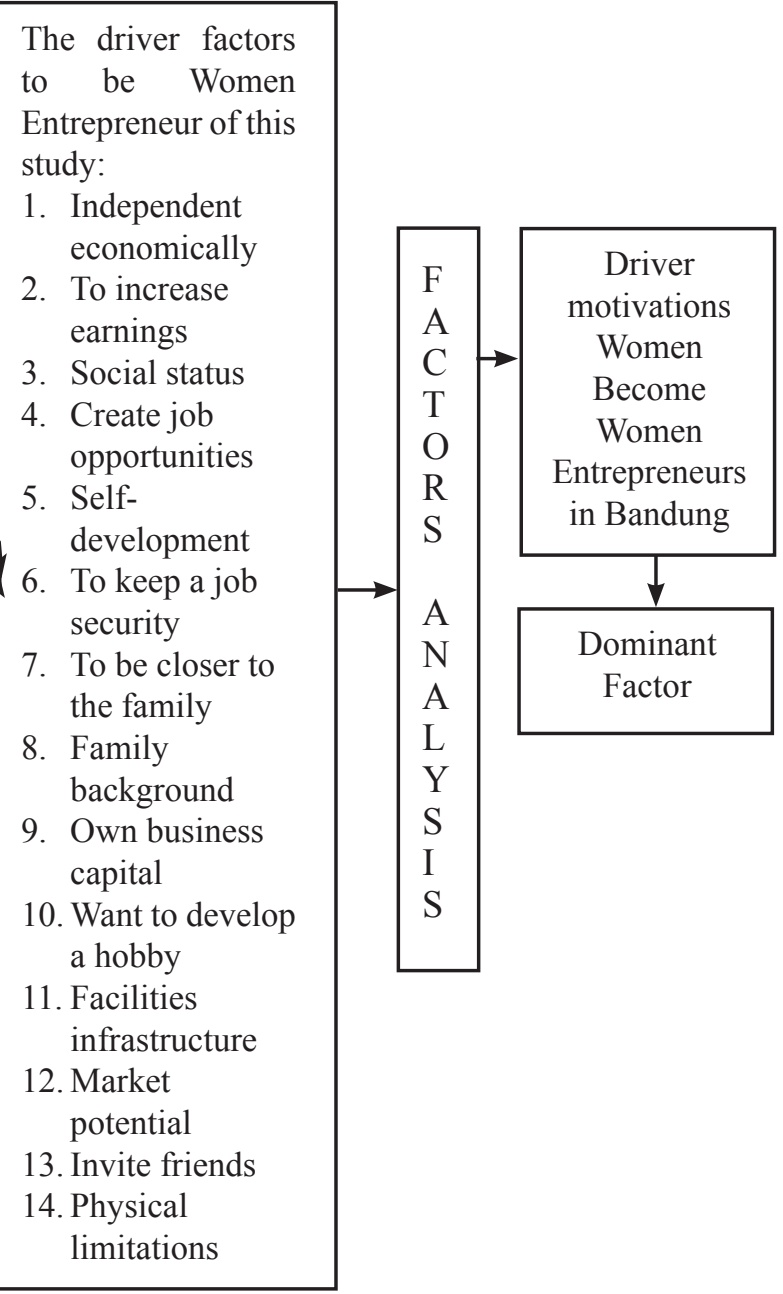

Table 1. KMO and Bartlett's Test

\begin{tabular}{lcc}
\hline Kaiser-Meyer-Olkin Measure of Sampling Adequacy &, 760 \\
\hline Bartlett's Test of Sphericity & Approx. Chi-Square & 930,547 \\
& Df & 210 \\
& Sig. &, 000 \\
\hline
\end{tabular}

Table 2. Anti Image Matrics

\begin{tabular}{ll}
\hline Factors & MSA \\
\hline Having fixed cash & 0.697 \\
Feeling not satisfied with the existing income & 0.660 \\
Feeling sufficient with family needs & 0.797 \\
Wanting to exist in the community & 0.631 \\
Wanting to have a bigger action in society & 0.598 \\
Creating job opportunities for family members & 0.859 \\
Looking forward to challenges & 0.772 \\
Making use of free time & 0.790 \\
Having work for family members & 0.777 \\
Maintaining the sustainability of family income & 0.832 \\
Running a business while doing housework & 0.667 \\
\hline
\end{tabular}

\begin{tabular}{lc}
\hline Factors & MSA \\
\hline Having more time with family & 0.777 \\
Parents are entrepreneurs & 0.731 \\
Majority of family members are entrepreneurs & 0.745 \\
Having unused funds & 0.806 \\
Having a hobby that can be a business & 0.785 \\
Being able to take on challenges and risks & 0.651 \\
Having facilities to support business activities & 0.823 \\
There being a possibility of big profit & 0.875 \\
Imitating friends for the success of their business & 0.858 \\
Having physical limitations & 0.731 \\
\hline
\end{tabular}


Based on Table 3, it can be seen that the factor Being able to take on challenges and risks in doing business has the greatest value 0.845 , which means about $84.5 \%$ variant of variable 'Being able to take on challenges and risks in doing business' can be explained by a new component which is formed. The factor 'Majority of family members are entrepreneurs' has a 0.819 value, which means about $81.9 \%$ variant of variable can be explained by the new component. It is similar with other factors, provided that the greater the value of communalities generated, the closer the relationship between existing variables and new variables formed.

\section{Factoring Process}

The factoring process used in this study is the Principal Component Analysis (PCA) method based on the value of eigenvalues. If the eigenvalues value of component $>1$, then the component can be maintained in the factor analysis, but if the eigenvalues value in component is $<1$ then the component is untenable and not included in the new model. Result of factoring process the research in Table 4. From the data in Table 4 there are seven components or factors that have eigenvalues $>1$, so the factoring process stops at the seventh component only. Factors eight to twenty-one are not used as new component-formers because they have eigenvalues $<1$. Based on Table 4 there are 21 factors performed by factor analysis, each of which has variant $=1$. The total variant produced is $21 \times 1=21$. If the 21 factors are summarized into the formed factor, then the calculation is as follows:

Component $1: 27,821 / 21 \times 100 \%=132.48 \%$

Component $2: 11,295 / 21 \times 100 \%=53.79 \%$

Component $3: 8,239 / 21 \times 100 \%=39.23 \%$

Component $4: 7,667 / 21 \times 100 \%=36.51 \%$

Component $5: 5,869 / 21 \times 100 \%=27.95 \%$

Component $6: 5,441 / 21 \times 100 \%=25.91 \%$

Component $7: 4,798 / 21 \times 100 \%=22.85 \%$

From the total calculation, the seven factors formed will be able to explain $338.72 \%$ of the overall factor.

\section{Factor Grouping Process}

Factor grouping is used to determine the initial factors to become new factors. The grouping of factors is based on the value of the resulting matrix component. The matrix component shows the distribution of variables on the components that are formed based on its loading factor. The greater the value of the loading factor, the more proven that the factor is worthy to be incorporated into a new factor. In order for the process of grouping to become a perfect factor, the rotation of factors with

\begin{tabular}{lll}
\hline Factors & Initial & Extraction \\
\hline Having more time with family & 1,000 & 0,795 \\
$\begin{array}{l}\text { Parents are entrepreneurs } \\
\text { Majority of family members are } \\
\text { entrepreneurs }\end{array}$ & 1,000 & 0,760 \\
$\begin{array}{l}\text { Having unused funds } \\
\begin{array}{l}\text { Having a hobby that can be a } \\
\text { business }\end{array}\end{array}$ & 1,000 & 0,819 \\
$\begin{array}{l}\text { Being able to take on challenges } \\
\text { and risks }\end{array}$ & 1,000 & 0,645 \\
$\begin{array}{l}\text { Having facilities that support } \\
\text { business activities }\end{array}$ & 1,000 & 0,845 \\
$\begin{array}{l}\text { There being a possibility of big } \\
\text { profit }\end{array}$ & 1,000 & 0,696 \\
$\begin{array}{l}\text { Imitating friends for the success of } \\
\text { their business }\end{array}$ & 1,000 & 0,581 \\
\begin{tabular}{l} 
Having physical limitations \\
\hline
\end{tabular} & 1,000 & 0,627 \\
\hline
\end{tabular}

\section{varimax rotation can be seen Table 5.}

Table 3. Communalities

\begin{tabular}{|c|c|c|}
\hline Factors & Initial & Extraction \\
\hline Having fixed cash & 1,000 & 0,674 \\
\hline $\begin{array}{l}\text { Feeling not satisfied with the } \\
\text { existing income }\end{array}$ & 1,000 & 0,636 \\
\hline $\begin{array}{l}\text { Feeling sufficient with family } \\
\text { needs }\end{array}$ & 1,000 & 0,761 \\
\hline Wanting to exist in the community & 1,000 & 0,767 \\
\hline $\begin{array}{l}\text { Wanting to have a bigger action in } \\
\text { society }\end{array}$ & 1,000 & 0,767 \\
\hline $\begin{array}{l}\text { Creating job opportunities for } \\
\text { family members }\end{array}$ & 1,000 & 0,728 \\
\hline Looking forward to challenges & 1,000 & 0,696 \\
\hline Making use of free time & 1,000 & 0,671 \\
\hline Having work for family members & 1,000 & 0,691 \\
\hline $\begin{array}{l}\text { Maintaining the sustainability of } \\
\text { family income }\end{array}$ & 1,000 & 0,646 \\
\hline $\begin{array}{l}\text { Running a business while doing } \\
\text { housework }\end{array}$ & 1,000 & 0,736 \\
\hline
\end{tabular}


Table 4.Total variance explained

\begin{tabular}{|c|c|c|c|c|c|c|c|c|c|}
\hline \multirow{2}{*}{$\begin{array}{l}\text { Com- } \\
\text { ponent }\end{array}$} & \multicolumn{3}{|c|}{ Initial eigenvalues } & \multicolumn{3}{|c|}{ Extraction sums of squared loadings } & \multicolumn{3}{|c|}{ Rotation sums of squared loadings } \\
\hline & Total & $\begin{array}{c}\% \text { of } \\
\text { Variance }\end{array}$ & $\begin{array}{c}\text { Cumulative } \\
\%\end{array}$ & Total & $\begin{array}{c}\% \text { of } \\
\text { Variance }\end{array}$ & $\begin{array}{c}\text { Cumulative } \\
\%\end{array}$ & Total & $\begin{array}{c}\% \text { of } \\
\text { Variance }\end{array}$ & $\begin{array}{c}\text { Cumulative } \\
\%\end{array}$ \\
\hline 1 & 5.842 & 27.821 & 27.821 & 5.842 & 27.821 & 27.821 & 2.881 & 13.721 & 13.721 \\
\hline 2 & 2.372 & 11.295 & 39.116 & 2.372 & 11.295 & 39.116 & 2.858 & 13.611 & 27.332 \\
\hline 3 & 1.730 & 8.239 & 47.355 & 1.730 & 8.239 & 47.355 & 2.292 & 10.912 & 38.244 \\
\hline 4 & 1.610 & 7.667 & 55.022 & 1.610 & 7.667 & 55.022 & 1.826 & 8.697 & 46.941 \\
\hline 5 & 1.233 & 5.869 & 60.891 & 1.233 & 5.869 & 60.891 & 1.820 & 8.668 & 55.608 \\
\hline 6 & 1.143 & 5.441 & 66.332 & 1.143 & 5.441 & 66.332 & 1.637 & 7.796 & 63.405 \\
\hline 7 & 1.006 & 4.789 & 71.121 & 1.006 & 4.789 & 71.121 & 1.620 & 7.716 & 71.121 \\
\hline 8 & 0.748 & 3.564 & 74.685 & & & & & & \\
\hline 9 & 0.708 & 3.370 & 78.054 & & & & & & \\
\hline 10 & 0.678 & 3.231 & 81.285 & & & & & & \\
\hline 11 & 0.624 & 2.972 & 84.257 & & & & & & \\
\hline 12 & 0.533 & 2.538 & 86.794 & & & & & & \\
\hline 13 & 0.493 & 2.346 & 89.141 & & & & & & \\
\hline 14 & 0.439 & 2.091 & 91.232 & & & & & & \\
\hline 15 & 0.394 & 1.876 & 93.109 & & & & & & \\
\hline 16 & 0.371 & 1.768 & 94.877 & & & & & & \\
\hline 17 & 0.317 & 1.510 & 96.387 & & & & & & \\
\hline 18 & 0.262 & 1.249 & 97.636 & & & & & & \\
\hline 19 & 0.214 & 1.019 & 98.654 & & & & & & \\
\hline 20 & 0.175 & 0.833 & 99.487 & & & & & & \\
\hline 21 & 0.108 & 0.513 & 100.000 & & & & & & \\
\hline
\end{tabular}

After the factor rotation, in Table 5 it can be seen that the initial factors have been completely dispersed into new factors $1,2,3,4,5,6$, and 7 . These seven new factors can be grouped as follows:

a. Factor I : Running a business while doing housework, having more time with family, creating job opportunities for family members, and there being a possibility of big profits.

b. Factor II : Majority of family members are entrepreneurs, parents are entrepreneurs, imitating friends for the success of their business, and having unused funds.

c. Factor III : Having a fixed cash, feeling not satisfied with existing income, feeling sufficient with family needs, and maintaining family income stability.

d. Factor IV : Having a hobby that can be used as business, having facilities that support business activities, and making use of free time.

e. Factor $\mathrm{V}$ : Wanting to have a bigger action in society, and wanting to exist in society.

f. Factor VI : Being able to take on challenges and risks, and looking forward to challenges. g. Factor VII : Having physical limitations, and having work for family members.

\section{Labelling}

Based on 21 variables put into factor analysis, finally 7 factors are formed. These factors are interpreted by the highest loading factor value of each factor. Here is the naming of factor in this research is based on the highest loading factor value. The seven factors can be seen in the Table 6 .

Based on Table 6, it can be seen that the Family Oriented factor is the first factor because the decision to become an entrepreneur is often chosen by women especially members of APPU West Java. Their reason is in line with the statement of Setiawati and Paramitha (2011) that women have different ways and strategies of doing business from men; women prefer to run businesses that are still within the scope of their daily activities and cannot be separated from household activities for they are already married. This statement is also supported by Safitri and Hatammimi's research 
(2014) that puts family factors as the main factor that motivates a woman to become an entrepreneur. In addition, according to Anggarwati (2012) by opening up a business, a woman can help the people around to increase their income, reduce unemployment, make the environment more conducive, and even create jobs especially for the people closest to them (the family).

Family Background and Friends factors are also influential in encouraging women's decisions to become entrepreneurs. With parents' background as enterpreneurs, family members and friends whose majority are also entrepreneurs, the growth of entrepreneurial spirit in a person can increase. Entrepreneurship interest does not arise from birth, but grows and develops according to the factors that influence it (Nasrullah, 2016). In addition, the women entrepreneur of APPU West Java's members often choose entrepreneurship to maintain the Income Stability. In a study conducted by Barani and Dheepa (2013) states that one of the drivers of an entrepreneurial woman is the need to earn income (money) that occupy the top factor.

Table 5. Rotated component matrix

\begin{tabular}{lccccccc}
\hline & \multicolumn{7}{c}{ Component } \\
\hline & 1 & 2 & 3 & 4 & 5 & 6 & 7 \\
\hline Having fixed cash & -0.047 & -0.119 & 0.786 & 0.007 & 0.020 & 0.197 & -0.015 \\
Feeling not satisfied with the existing income & 0.150 & 0.206 & 0.726 & 0.068 & 0.080 & -0.144 & 0.109 \\
Feeling sufficient with family needs & 0.356 & 0.162 & 0.712 & 0.253 & 0.077 & -0.130 & -0.122 \\
Wanting to exist in the community & -0.092 & 0.194 & 0.250 & 0.067 & 0.766 & 0.011 & 0.258 \\
Wanting to have a bigger action in society & 0.148 & 0.055 & -0.082 & -0.055 & 0.810 & 0.208 & -0.182 \\
Creating job opportunities for family members & 0.770 & 0.252 & 0.252 & -0.010 & 0.034 & 0.044 & 0.074 \\
Looking forward to challenges & 0.373 & 0.172 & 0.173 & 0.232 & 0.391 & 0.532 & 0.081 \\
Making use of free time & 0.155 & 0.079 & 0.040 & 0.517 & 0.408 & 0.043 & 0.452 \\
Having work for family members & 0.048 & 0.219 & 0.314 & -0.076 & 0.273 & 0.225 & 0.641 \\
Maintaining the sustainability of family income & 0.445 & 0.259 & 0.517 & -0.051 & 0.012 & 0.332 & -0.005 \\
Running a business while doing housework & 0.843 & -0.094 & 0.058 & 0.086 & 0.040 & 0.052 & -0.044 \\
Having more time with family & 0.818 & 0.019 & 0.035 & 0.240 & 0.025 & 0.123 & 0.224 \\
Parents are entrepreneurs & -0.015 & 0.773 & 0.063 & 0.217 & 0.096 & 0.066 & 0.324 \\
Majority of family members are entrepreneurs & 0.085 & 0.831 & 0.112 & 0.189 & 0.084 & 0.132 & 0.220 \\
Having unused funds & -0.049 & 0.593 & 0.029 & 0.077 & -0.095 & 0.407 & 0.331 \\
Having a hobby that can be a business & 0.247 & 0.058 & 0.098 & 0.792 & -0.012 & 0.116 & 0.087 \\
Being able to take on challenges and risks & 0.122 & 0.066 & -0.021 & 0.201 & 0.157 & 0.872 & -0.016 \\
Having facilities that support business activities & -0.023 & 0.421 & 0.074 & 0.669 & -0.064 & 0.241 & -0.072 \\
There being a possibility of big profit & 0.470 & 0.390 & 0.091 & 0.370 & 0.199 & 0.032 & -0.323 \\
Imitating friends for the success of their business & 0.196 & 0.678 & 0.091 & -0.020 & 0.220 & -0.105 & -0.119 \\
Having physical limitations & 0.134 & 0.272 & -0.234 & 0.123 & -0.160 & -0.142 & 0.648 \\
\hline
\end{tabular}

Table 6. Labelling

\begin{tabular}{lc}
\hline Name of factors & Variance \\
\hline Family oriented & $132.48 \%$ \\
Family background and friends & $53.79 \%$ \\
Income stability & $39.23 \%$ \\
Hobby and facility support & $36.51 \%$ \\
Public existence & $27.95 \%$ \\
Challenges and risks & $25.91 \%$ \\
Physical limitation & $22.85 \%$ \\
\hline
\end{tabular}


Meanwhile, there are also women who decide to become entrepreneurs by developing a hobby that they often do, especially if accompanied by the availability of production equipment owned, so it is natural if the factor of Hobby and Facility Support has been chosen to be one of the driving factors to become women entrepreneurs. According to Putra (2012), the opportunity is an opportunity earned by a person or also the ability to see things in different perspectives. Thus, by knowing business opportunities from hobby, very often the products of women entrepreneurs are very interesting in the market. In fact, some women entrepreneurs in APPU West Java claimed to be pushed to be entrepreneurs because they want to get Public Existency. This is in line with the increasing number of women who participate actively economically in the surrounding environment as well as the larger scope of society (Jati, 2009), so they can be better known by the community and can play a bigger role for the environment. This is in line with the statement of Setiawati and Paramitha (2011) which state that there are many women who do business not to enrich themselves, but to share and devote attention to the social, humanitarian, and environment.

Having a risk taker spirit is also one of the reasons why a person is interested in entrepreneurship, because with entrepreneurship they can get more challenges and risks than just being employees with standardized and specific job. Armiati (2013) mentions that one of the drivers of a woman to become an entrepreneur is to take risks. Entrepreneurship spirit is not only felt by women entrepreneurs with perfect physics, but also by some women entrepreneurs of APPU members with physical limitations; entrepreneurship has become a decision taken, because not all companies accept people with physical limitations as their employees. By becoming entrepreneurs, women with physical limitations directly or indirectly want to prove that physical limitations are not a barrier to their activities as well as to eliminate negative stigma in society (Winasti, 2012).

\section{Managerial Implications}

This research has a managerial implication for APPU organization as it inspires APPU to determine what type of training is suitable for members whose greatest motivation is the family. APPU could design training for culinary, fashion, convection, and creative industry for women. The government of West Java should also be able to provide operational facilities required by APPU West Java, so this association can be more productive in the development of entrepreneurship, women entrepreneurship, and capital and financial assistance support.

\section{ACKNOWLEDGMENTS}

With the completion of this paper, the authors would like to thank their parents who always pray for them, Business Administration Department of Telkom University that has facilitated them, APPU West Java as the research partner, and other researchers and reference sources that have helped finish the research.

\section{CONCLUSIONS AND RECOMMENDATIONS}

\section{Conclusions}

Based on the factor analysis in this study, it can be seen that there are seven groups of motivations that encourage women to become women entrepreneurs in the members of Asosiasi Pemasar Produk UKM (APPU) West Java domiciled in Bandung. These factors are Family Oriented, Family Background and Friends, Income Stability, Hobby and Facility Support, Public Existency, Challenges and Risks, and Phisycal Limitation. The most dominant factor is Family Oriented factor which consists of variable running business as well as doing housework, having more time with family, creating job opportunity for family member, and the possibility of big profit.

\section{Recommendations}

For further research, the seven groups of motivation can be tested through empirical research with more respondents of women entrepreneurs. The empirical research can be conducted to understand the contribution toward business performance and sustainability of business from financial perspective, marketing and sales perspective and innovation capability of enterprise.

Based on the results of research, the authors try to provide suggestions and inputs that hopefully can be useful for the parties concerned in this study; the suggestions include: (1) APPU West Java as one of the associations that overshadow the owners of small and medium enterprises (SMEs) in West Java whose majority members are women entrepreneurs should 
be able to increase the motivation of members and understand the needs of members in running the business and develop other strategies to further encourage members to actively participate. This is because not a few members of APPU West Java, especially women entrepreneurs who are still registered as members, but are passive. There are several suggestions that the author tries to convey to women entrepreneurs, among others no hesitation in making a decision to become an entrepreneur, more innovative and dare to open business in other fields, so it is not only dominated by culinary and fashion, and more active to use the internet in product marketing, so that the product can be recognized by more consumers.

\section{REFERENCES}

Alifuddin M, Razak M. 2015. Kewirausahaan: Strategi Membangun Kerajaan Bisnis. Cetakan Ke-1. Jakarta Timur: MagnaScript Publishing.

Amirullah. 2013. Metodologi Penelitian Manajemen: disertai Contoh Judul Penelitian dan Proposal. Cetakan ke-1. Malang: Bayumedia Publishing.

Anggarwati MB. 2012. Analysis motivation women factors in building micro, small, and medium enterprises Depok [skripsi]. Depok: Universitas Gunadharma.

Armiati. 2013. Women entrepreneurs serta faktor-faktor yang mempengaruhinya (kasus pada pengrajin sulaman wanita di Jorong Lundang Kanagarian Panampuang Kab. Agam). ECONOMICA Journal of Economic and Economic Education 1(2):162-174.

Barani G, Dheepa T. 2013. Influence of motives and its impact on women entrepreneurs of India. Journal of Entrepreneurship and Management 2(2):24-30.

Fahmi I. 2013. Kewirausahaan: Teori, Kasus dan Solusi. Bandung: Alfabeta.

Frank AK. 2012. Factors motivating women\&\#39;s informal micro-entrepreneurship. International Journal of Gender and Entrepreneurship 4(1).

Jesurajan SVA, Gnanadhas E. 2011. A Study on The Factors Motivating Women to Become Entrepreneurs in Tirunelveli District. Asian Journal of Business and Economics 1(1):1-14.
Kumar SM, Mohan HSC, Vijaya C, Lokeshwari N. 2013. The Role of Women Entrepreneurship in Modern World. International Journal of Current Engineering and Technology Special Issue1 (Sept 2013):100-104.

Munawaroh M. 2012. Faktor-Faktor Yang Memotivasi Wanita Menjadi Pengusaha (Studi pada Pengusaha Wanita Anggota Iwapi DIY). Ilmu Manajemen 2 (1):32-43.

Nasrullah M. 2016. Pengaruh jiwa kewirausahaan dan latar belakang orang tua terhadap minat berwirausaha siswa SMK An Nur Bululawang Malang [skripsi]. Malang: UIN Malang.

Nurlinawati. 2017. Pengaruh motivasi terhadap pemilihan wanita pada wirausaha salon kecantikan di Samarinda Hilir. E-Journal Administrasi Bisnis 5(2).

Putra RA. 2012. Faktor-faktor penentu minat mahasiswa manajemen untuk berwirausaha. Jurnal Manajemen 1(1):1-15.

Safitri TY, Hatammimi J. 2014. Analisis faktor- faktor yang memotivasi wanita berwirausaha melalui bisnis online (studi pada mahasiswa sekolah bisnis di Bandung). Jurnal Internal Universitas Telkom 1-8.

Sarwono J. 2012. Path Analysis dengan SPSS: Teori, Aplikasi, Prosedur Analisis untuk Riset Skripsi, Tesis, dan Disertasi. Jakarta: PT. Elex Media Komputindo.

Setiawati T, Paramitha A. 2011. Motivasi Ibu Rumah Tangga dalam Berwirausaha (Studi Kasus Tiga Wirausaha Handicraft di Yogyakarta). dalam: Seminar Bersama antara Prodi Manajemen FE UII dan Graduate School pf Business (GSB) Fakulti Ekonomi dan Perniagaan Univversiti Kebangsaan Malaysia 22 Nopember 2011 di Yogyakarta.

Sujarweni, V. Wiratna. 2015. Metodologi Penelitian Bisnis dan Ekonomi. Cetakan ke-1.Yogyakarta: Pustakabarupress.

Winasti M. 2012. Motivasi berwirausaha pada penyandang disabilitas fisik. EMPATHY 1(1).

Zimmerman MA, Chu HM. 2013. Motivation, success, and problems of entrepreneurs in Venezuela. Journal of Management Policy and Practice 14(2):1-15. 